\title{
You Are Not My Customer ${ }^{\text {(Note 1) }}$
}

\author{
Keith Burgess-Jackson (Corresponding author) \\ Department of Philosophy and Humanities, The University of Texas at Arlington \\ Box 19527, Arlington, TX 76019-0527, USA \\ Tel: 1-817-272-2764Ｅ-mail:kbj4@att.net; kbj@uta.edu
}

Received: August 18, 2020 Accepted: September 11, 2020

Published: September 20, 2020

doi:10.5296/jei.v6i2.17547ＵRL: https://doi.org/10.5296/jei.v6i2.17547

\begin{abstract}
I argue that it is degrading (and therefore insulting) for university administrators to refer to students as "customers" or "consumers" and to refer to instructors as "vendors" or "service-providers." There is nothing inherently wrong with economic analysis, much less with economics as an academic discipline; nor is there anything objectionable per se about commerce or the commercialization of (mere) things; but economic terminology must not be allowed to encroach on institutions, practices, or relationships (such as the teacher-student relationship) that have special meaning and value.
\end{abstract}

Keywords: Education, Teaching, Economics, Students, Instructors, Administrators, Degradation, Commercialism

[N]othing of great value is either abstract or commensurate. Start with your hand. The workman's compensation office can tell you the value of your hand in dollars. Consider your daughter. An insurance company or litigation lawyer can tell you her value in dollars. What is your home place worth? Your lover's hair? A stream? A species? Wolves in Yellowstone? Carefully imagine each beloved person, place, animal, or thing redescribed in economic language. Then apply cost-benefit analysis. What results is a feeling of sickness familiar from any forest sale or predator-control proposal. It is the sickness of being forced to use a language that ignores what matters in your heart (Turner, 1996, p. 64).

\section{Introduction}

By now you have heard the lingo. You have heard a university administrator (or someone else 
on campus) refer to students as "customers" or "consumers." By paying tuition, it is said, you are purchasing goods and services. Those who teach you-quaintly known as instructors, teachers, masters, or professors - are to be called (and, more importantly, thought of as) "vendors" or "service-providers." There is said to be a "market" for education. Indeed, education itself is coming to be viewed in some quarters as "training" or "information delivery."

Perhaps this new language - this jargon, this argot, this patois, this façon de parler - appeals to you. It may sound reassuringly familiar. After all, we live in a "new economy." Those who have marketable skills are supposed to flourish, whereas those who allow their talents to rust are sure to languish (or, worse, perish). There are other reasons besides familiarity why a student may prefer the new language. In the marketplace, as the adage goes, the customer is always right. Consumers, like those accused of crimes, have legally protectable interests (i.e., rights). Those who ignore, disrespect, or otherwise slight their patrons may find themselves out of business, an ignominious end indeed. To have money, in a commercialized, materialistic society such as ours, is to have power - both power-to and, more problematically, power-over (Note 2).

In this essay, I hope to persuade you-or rather, remind you, since, deep down, you know it - that this picture of students as customers, instructors as vendors (or service-providers), and universities as business firms is degrading (hence insulting) to all concerned. The sooner we realize this, the sooner we will be rid of the inappropriate and demeaning lingo; and the sooner we are rid of the lingo, the better off we'll be, both individually and collectively. If I were a student, I would resent being called (or even thought of as) a customer. I hope that by the end of this essay you see why.

\section{Reduction and Degradation}

Let me begin with a simple example. A nickel (the one with Thomas Jefferson's image on it) is not just a nickel; it is a physical object, a piece of metal, a piece of nickel (or nickel alloy) (Note 3), and a coin (among other things). Each of these descriptions is true. What this shows is that there can be multiple true descriptions of, or labels for, the same object. To a physicist, the salient description is "physical object." To a metallurgist, the salient description is "piece of nickel (or nickel alloy)." To a coin collector, the salient description is "coin" (specifically, "nickel," or "five-cent piece"). We can take the example a step further. The nickel in question may have special features. If it were minted in 1950 in Denver, Colorado, then it is what numismatists (a fancy name for those who study or collect coins) call a 1950-D nickel. Since there were comparatively few of these produced (take my word for it), it is worth more, in economic terms, than a run-of-the-mill nickel.

Nickels cannot feel degraded, as humans can, but if they could, they would be insulted by the description "piece of metal," or even "coin," however apt these descriptions may be. I can imagine a nickel shouting, "I'm not just a piece of metal, dammit; I'm a coin, and a pretty impressive one at that!" Think of it this way. All 1950-D nickels are nickels, but not all nickels are 1950-D nickels. All nickels are coins, but not all coins are nickels. All coins are pieces of metal, but not all pieces of metal are coins. All pieces of metal are physical objects, but not all physical objects are pieces of metal. 
To reduce a thing, philosophically, is to (re)describe it in less specific language, to put it into a class with other things in a way that obscures its uniqueness or specificity. It is to take a unique, special, or extraordinary thing and render it mundane, generic, or ordinary. Describing a 1950-D nickel as a "piece of metal," though true, and though useful in certain contexts, puts it into a category with brass nails, pewter spoons, aluminum cans, and gold tooth fillings (Note 4).

As I say, nickels cannot feel degraded. (To degrade - de-grade - is to reduce or lower the grade or status of a thing.) But wouldn't you feel degraded if someone ignored your unique or special features, or some special relationship you have to others, and treated you as a generic person? We know that every human being is (to put it indelicately) a bag of chemicals. But who wants to be thought of, or described, as a bag of chemicals? I don't! To think of me in that way is to miss what is distinctive of me. For one thing, I am a thinking bag of chemicals. I have a mind, a personality, volition, and sensation. To describe me as a bag of chemicals, or as a physical object, or even as a biological organism, is to lower my status. How insulting! I resist being reduced in this way, and I question the motives of anyone (including a scientist) who attempts it.

If someone describes me as a physical object, thereby lumping me in with the computer on which I write these words and the cup from which I sip my coffee, I begin to wonder whether the next step is to treat me as a physical object. I will be particularly vigilant in detecting reductionist terminology, for that is the tangible expression - the indicator, if you will — of how I am being conceived. Whenever someone describes me as anything other than as a person (a morally exalted state, to be sure), I will remind him or her that it understates the case - perhaps, depending on the description, vastly so (Note 5).

\section{The Specialness of the Teacher-Student Relationship}

You can probably see where this is going. With all due respect to university administrators (some of whom, believe it or not, are my friends), describing students as "customers" or "consumers" ignores what is special about them. It treats them like K-Mart shoppers searching for blue-light specials (commodities) or like weary athletes contracting for massages (services). Is that a flattering, uplifting, ennobling description? Do you feel good thinking of yourself in that way, or knowing that others, with power over you, think of you in that way? I wouldn't. I would be the opposite of flattered; I would be insulted (and perhaps outraged).

To me, the relationship between teacher and student, master and pupil, custodian and charge, is special. Not to sound corny, but it is as sacred a relationship as there is in our secularized culture. Teachers (the good ones, anyway) care about the souls of their students, not just about their marketability. They try to instill character as well as train the intellect. The knowledge that they impart, and the skills that they inculcate, are those that the teachers deem intrinsically, and not just instrumentally, worthy (Note 6). Henry Simon's advice to fledgling teachers is as sound today as it was when he offered it more than 80 years ago:

Your job, if you teach any subject that is less obviously 'cultural' than music or the fine arts, is to make of it too a truly cultural subject. That means that you must develop 
your pupils fundamentally, must make of them fuller, richer persons mentally, physically, or morally, must develop their awareness of things, their understandings, and their powers of appreciation and expression. Any teaching which does not get under the pupils'skin and make them eventually different and better persons might almost as well not take place at all (Simon, 1938, p. 31) (Note 7).

Good teachers know that most learning, and certainly all durable learning, is self-effected. What good teachers try to do is facilitate or enable - i.e., make possible - a lifetime of curiosity, discovery, and edification. This is why all the instructors I know, at my university and elsewhere, care deeply about where their students go and what they do. Nothing is as satisfying to the professorial mind, or so warms the pedagogical heart, as seeing one's pupils succeed. Not in the base economic sense of accumulating wealth, status, or power, for these, in the scheme of things, are hollow, but in the sense of contributing to the life prospects, happiness, and well-being of others (including, I hasten to add, nonhuman animals) (Note 8).

\section{The Perils of Commercialization}

Is there anything wrong, per se, with the language of economics (or commerce)? The answer is no. Economists (the good ones, at any rate) have enhanced our understanding of almost all social phenomena, even those that would appear to have nothing to do with markets and prices. Here is Richard Posner, an economically minded lawyer (and at the time a federal appellate judge), on marriage:

There is a substitute in marriage for the control mechanisms within a business firm. Economists naturally do not call this factor "love," but describe it as a form of altruism. Altruism is the condition in which the welfare of one person is a positive function of the welfare of another. If $H$ loves $W$, then an increase in W's happiness or utility or welfare (synonyms) will be felt by $H$ as an increase in his own happiness or utility or welfare. Altruism facilitates cooperation; it is a cheap and efficacious substitute for (formal) contracting (Posner, 1998, p. 157).

Here is Posner on children:

We [i.e., Posner and his fellow economists] have treated children as an ultimate "commodity," but it is possible to treat them instead as an input into other commodities. The economist speculates that children are produced (1) as an unintended by-product of sexual activity, (2) as an income-producing investment, (3) as a source of other services to the parents, and (4) (really a subset of (3)) out of an instinct or desire to preserve the species or perpetuate the genetic characteristics, the name, or the memory of the parents. ... Liking children is a subset of (3): The pleasure we get from our children's presence is the result of "consuming" the intangible "services" that they render us (Posner, 1998, p. 158).

Are you surprised, when you read these passages, that economics is called "the dismal science"? (Note 9). It is said, perhaps unfairly, that economists know the cost of everything and the value of nothing (Note 10). 
I don't want to be too hard on economists. They alone are not responsible for the encroachment of their language into areas where it does not belong. Posner, for example, is not advocating that spouses view themselves as utility-maximizers or as rational economic agents; he is claiming that viewing them in this way (i.e., under these aspects or rubrics) explains much or all of their behavior. Economic analysis, as a social-scientific theory or method, is powerful and illuminating - qualities to which every science aspires. Nor is Posner trying to eliminate the language of love. He is saying that the phenomenon we call love can (not "should") be understood in economic terms. In other words, love is reducible to, or explicable in terms of (though not ultimately eliminable in favor of), something else. Economists, when confined to the realm of explanation, are harmless (maybe even lovable).

The problem arises when economic discourse escapes into, or trespasses onto, other domains, for then, like a tiger in a church, it is dangerous. Here is one example of its destructiveness:

Our habits and our vocabularies testify to this commingling of the [commercial and democratic] spheres. We form an increasingly seamless web between friends and lovers, and the business acquaintances with whom we buy and sell and connect and "network." Consider only dating, that subject of which our culture never tires. Dating (as movies and television shows and novels depict it) gives people the opportunity to shop around and to find just the right partner. Until we achieve the perfect fit, we dump boyfriends and girlfriends like traders getting rid of declining shares. Eventually we hope to close a deal and find a partner for life, but having learned to be choosy consumers in the romantic marketplace, it is not easy to cease being constantly on the lookout for a new, improved model. Commercial reflexes have infested the most intimate corners of our lives, unless we actively resist them (Berkowitz, 2001, p. 45).

Every rational person, as such, is responsible for his or her actions, including that subset of actions known as speech (or linguistic) acts (Note 11). Thus, university administrators are responsible (accountable, answerable) for the language they use to describe students and instructors on their campuses. If you find their language debasing, degrading, demeaning, and insulting, as I do, then you should resist it. The most important component of this resistance is to cease thinking of yourself (assuming you do or have done so) as a "consumer" of an "educational product" (Note 12).

If you conceive of your instructors as vendors or service-providers, then you are lumping them in with those who repair washing machines for a living. This is not to disparage those who repair washing machines for a living, but I suspect that they care not a whit for the "souls," happiness, or intellectual well-being of the people who pay their fees. The relationship - any commercial relationship - is conducted at arm's length. It is shallow rather than deep, narrow rather than broad, one-dimensional rather than multi-dimensional, impersonal rather than personal (Note 13).

\section{Conclusion}

The bottom line (pardon the commercial metaphor!) is this: If you want your relationship with 
your instructors to be, and to remain, special; if you believe, as I do, that the teacher-student relationship is sacrosanct (like that of parent and child, minister and parishioner, doctor and patient, friend and friend); then let your language reflect your understanding. Do not stop there, however. Go out of your way (civilly, of course) to condemn - that is, to express respectful resentment toward - anyone who tries to reduce you to a customer. You, my dear student, are much more than a customer (Note 14).

\section{Acknowledgements}

Counting kindergarten, I was a student for 27 years, during which time I had many talented, dedicated, and inspirational teachers. This essay is dedicated to those I remember most fondly: Mrs Hunkins (my fifth-grade teacher at Vassar Middle School in Vassar, Michigan); Marilyn Agan (my French teacher at Vassar High School); Richard A. Gull, John B. Schroeder, and Bruce A. Rubenstein (at the University of Michigan-Flint); Edward M. Wise, Robert A. Sedler, and Vincent A. Wellman (at Wayne State University Law School); Bruce A. Russell, Marc W. Kruman, and Corinne Lathrop Gilb (at Wayne State University); and Joel Feinberg, Allen E. Buchanan, and Alvin I. Goldman (at the University of Arizona). None of these wonderful teachers, I am sure, viewed me as a customer, and I certainly did not view any of them as a service-provider.

\section{References}

Berkowitz, P. (2001). Money and love. Review of Economic Sentiments: Adam Smith, Condorcet, and the Enlightenment, by Emma Rothschild. The New Republic: A Journal of Politics and the Arts, 225, 41-45.

Heilbroner, R. L. (1961). The worldly philosophers: The lives, times, and ideas of the great economic thinkers (Rev. ed.). New York, NY: Simon and Schuster.

Leftwich, R. H. (1966). The price system and resource allocation (3rd ed.). New York, NY: Holt, Rinehart and Winston.

Mohr, R. D. (1988). The ethics of students and the teaching of ethics: A lecturing. In R. D. Mohr, Gays/Justice: A study of ethics, society, and law (pp. 293-311). New York, NY: Columbia University Press.

Posner, R. A. (1998). Economic analysis of law (5th ed.). New York, NY: Aspen Law and Business.

Rhoads, S. E. (1985). The economist's view of the world: Government, markets, and public policy. Cambridge, England: Cambridge University Press.

Ryle, G. (1954). Dilemmas. Cambridge, England: Cambridge University Press. https://doi.org/ 10.1017/CBO9781316286586

Sagoff, M. (1988). The economy of the earth: Philosophy, law, and the environment. Cambridge, England: Cambridge University Press.

Searle, J. R. (1969). Speech acts: An essay in the philosophy of language. Cambridge, England: 
Cambridge University Press. https://doi.org/10.1017/CBO9781139173438

Searle, J. R. (1979). Expression and meaning: Studies in the theory of speech acts. Cambridge, England: Cambridge University Press. https://doi.org/10.1017/CBO9780511609213

Simon, H. W. (1938). Preface to teaching. New York, NY: Oxford University Press.

Turner, J. (1996). The abstract wild. Tucson, AZ: The University of Arizona Press.

Wartenberg, T. E. (1990). The forms of power: From domination to transformation. Philadelphia, PA: Temple University Press.

\section{Notes}

Note 1. This essay was written for my students at the University of Texas at Arlington - hence the colloquial language. I believe it will be of interest to students (and instructors) at other colleges and universities as well.

Note 2. For a discussion of these types of power, see Wartenberg, 1990, p. 18.

Note 3. The Jefferson nickel is one-quarter nickel and three-quarters copper, according to Wikipedia.

Note 4. Some philosophers (and others) dream of a grand cascading reduction. Social sciences such as sociology, they say, are reducible to psychology, which in turn is reducible to biology, which is reducible to chemistry, which is reducible to physics, which is reducible to mathematics, which is reducible to logic (the core, not coincidentally, of philosophy). Not all reductionists are eliminativists. The latter wish to eliminate the language of the reduced field. For example, once psychology is reduced to biology, there will be no need for psychological terminology; it will (and should) be eliminated from our vocabulary. We will no longer "talk that way," and anyone who persists in doing so will be treated as superstitious, the way astrologers and alchemists are treated as superstitious. Those reductionists who are not eliminativists have no principled objection to continued use of the terminology of the reduced field, but they believe that it is inferior to the terminology of the field to which it has been reduced.

Note 5. The philosopher Gilbert Ryle makes essentially the same point: "Mechanical principles contain the explanations of all bodily states and processes. But plants, insects, animals and men are bodily organisations. So all their states and processes can be mechanically explained. Yet living things are not merely complex mechanisms; the biological sciences are not mere off-shoots of mechanics. Where there is life there is purposiveness, and where there is sentient, mobile and, especially, conscious and intellectual life there are progressively higher and higher levels or types of purposiveness" (Ryle, 1954, p. 125 [emphasis added]).

Note 6. A thing is valued intrinsically when it is valued for its own sake, independently of anything else that it may, or does, bring about. A thing is valued instrumentally (i.e., extrinsically) when it is valued for its propensity to bring about something intrinsically valuable. 
Logically speaking, a given object can be valued both intrinsically and instrumentally. Some people cite friendship and knowledge as examples of this.

Note 7. Note that one aim of teaching, according to Simon, is to transform one's students. This involves giving them what they need, not what they want. (Needs and wants can, and for most of us, much of the time, do, diverge.) The commercial marketplace doesn't just cater to wants; it manufactures them. I cannot resist quoting the philosopher Richard Mohr, who believes that "The proper function of high schools and compulsory public education in general—one that by default must be carried out by colleges - is the saving of students from their parents and their religion" (Mohr, 1988, p. 303).

Note 8. One insidious feature of economic thinking, or perhaps I should say "conventional economic thinking," is that it divides the world into two mutually exclusive and jointly exhaustive categories: humans and resources. The resources, as the name implies, are assumed to exist for human use and consumption. Sentient nonhuman life- e.g., birds, snakes, rabbits, dogs, and chipmunks - has value in this view only if, and only to the extent that, it is valued by humans, whether as means or as end. As one economist put it, "Economics is concerned with man's well-being. It encompasses the social relationships or social organization involved in allocating scarce resources among alternative human wants and in using those resources toward the end of satisfying wants as fully as possible" (Leftwich, 1966, p. 2). For an instructive critique of the economic way of thinking about nonhuman animals and the natural environment, see Sagoff, 1988.

Note 9. The expression "dismal science" was coined by Thomas Carlyle (1795-1881) upon reading the work of Thomas Robert Malthus (1776-1834). See Heilbroner, 1961, p. 61.

Note 10. See, e.g., Rhoads, 1985, p. 11.

Note 11. See Searle, 1969; Searle, 1979.

Note 12. Speaking, thinking, feeling, and acting are intimately related, of course - at least in those individuals who have an integrated personality. How we speak, for instance, both reflects and shapes (or reinforces) the way we think; and thinking is inseparable, logically and psychologically, from acting.

Note 13. Let me be clear about something. I am not against commerce. I am not even against commercialization (where the thing being commercialized is, well, a thing). I am against commercialism. This is the expansion of commerce, and its attendant conceptual scheme and terminology, into realms to which it does not belong. Think of the degradation of various holidays, such as Easter and Christmas. Think of the adverse effect commerce has had on such venerable institutions as religion, art, science, law, medicine, and the military. The university - academia - is not, and should not be conceived as, a commercial setting or institution. This is true even though economists, whose aim is to understand behavior, may find it useful to analyze universities (and the agents thereof) in economic terms. Recall the marriage example. Economic analysis can shed light on marriage without those involved (the spouses) viewing themselves as rational, self-interested, utility-maximizing contractors. By the same token, students, instructors, and administrators need not, and in my view should not, view 


\section{Macrothink}

themselves in economic or commercial terms.

Note 14. If, in spite of my plea, you persist in thinking of yourself as a customer (and of your instructors as vendors or service-providers), then please at least realize that what you are purchasing from them (or from the university that employs them) is not a particular grade, such as an "A" or a "B." What you are purchasing is the instructor's professional judgment as to the grade you have earned (on the basis of your demonstrated mastery of the relevant concepts, methods, and techniques of the field of study). What you are purchasing, in other words, is a chance to earn a good grade, not the grade itself.

\section{Copyright Disclaimer}

Copyright for this article is retained by the author(s), with first publication rights granted to the journal.

This is an open-access article distributed under the terms and conditions of the Creative Commons Attribution license (http://creativecommons.org/licenses/by/3.0/). 